\title{
Gender and Sexuality in Nazi Germany
}

\author{
Nicole Loroff
}

\begin{abstract}
In this paper, I survey Nazi ideals on gender and sexuality and illustrate how these ideals affected both German men and women. I also discuss how Nazi views on gender and sexuality were developed and enforced by the regime. I highlight the general contradictions apparent in Nazi policy on gender and sexuality. Ultimately, the purpose of my paper is to show that the non-Jewish German population was also impacted by Nazi policies.
\end{abstract}

It is often thought that Nazi ideology was primarily focused on removing the influence of Jews from all aspects of German society. However, Nazi ideas and attitudes towards race were far more complex. For the Nazi regime, establishing a pure and thriving Volk (community) was crucial to the survival of Germany and subsequently, the German people. ${ }^{1}$ Therefore, the Nazis saw themselves responsible for ensuring that the German/Aryan race flourished. In order to achieve their racial ambitions, the Nazis introduced a number of reforms that redefined Germany's existing social structures. These reforms also drastically limited personal freedoms of both Jewish and non-Jewish German citizens. Moreover, due to the authoritarian nature of Nazism, the regime sought to control the behaviour of people both in and out of the public sphere. Under Nazi rule, a person's body was no longer considered their own. Instead, the body was recognized as a public site. ${ }^{2}$ As a result, established social conceptions on gender and sexuality became susceptible to Nazi influence. To achieve their ideological objectives, the Nazi regime instituted a number of policies regarding gender and sexuality. Ultimately, these policies had a significant impact on German society. This paper will examine how Nazi ideology on gender and sexuality affected both men and women living in the Third Reich. Furthermore, this paper will illustrate that non-Jewish German citizens also bore the brunt of Nazi racial ideology.

\section{Gender Roles in Nazi Germany}

For the Nazis, existing social and behavioural norms that delineated gender roles in Germany were not conducive to their ideological ambitions. During their time in power, the Nazis worked to establish their own conceptions regarding gender in German society. Like other fascist movements, the Nazis subscribed to the idea of creating a 'new man' that would function as a symbol of the state. In promoting the concept of creating a 'new man', the Nazis redefined existing notions on manliness and masculinity. According to Nazi ideology, manliness could not be ascertained through "virtues that could be expressed in ordinary life."3 Instead, a man could only achieve true manliness by engaging in heroic activities, such as fighting in a war. Moreover, the Nazis believed that manliness was determined by a man's willingness to sacrifice himself for the greater good of the state. ${ }^{4}$ For the Nazis, the soldier embodied all the ideal characteristics associated with the 'new man'. Men were expected to embrace the soldier mentality and join male dominated organizations, such as

\footnotetext{
${ }^{1}$ Terri J. Gordon, "Fascism and the Female Form: Performance Art in the Third Reich," in Sexuality and German Fascism, ed. Dagmar Herzog (New York: Berghahn Books, 2005), 164.

2 Ibid., 164.

${ }^{3}$ George L. Mosse, The Image of Man: The Creation of Modern Masculinity (New York: Oxford University Press, 1996$), 167$.

${ }^{4}$ Ibid., 167.
} 
the SS (Schutzstaffel). Furthermore, in order to fulfil their racial duties, men were also encouraged to marry 'hereditarily fit' German women and establish kinderreich (rich in children) families. ${ }^{5}$ In the family unit, men were expected to act as patriarchs, charged with instilling proper Nazi values into their children. Thus, it is apparent that Nazi attitudes towards masculinity and the role of the man subscribed to a Germanic ideal.

Nazi views on the role of women also revolved around traditionalist ideals. According to Nazi doctrine, "...to be a wife and mother is the German woman's highest essence and purpose of life."6 Essentially, it was the responsibility of the 'hereditarily fit' woman to birth and raise racially pure children. As a result, femininity became synonymous with motherhood and fertility in the Third Reich. Furthermore, a high level of intelligence in a woman was no longer considered desirable

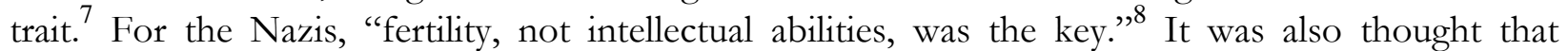
women should remain inside the home or private sphere because the public realm was strictly a man's world. In penetrating the public sphere, it was understood that a woman would not be able to accomplish her stately duties of birthing and raising pure Aryan children. In the home, women's activities were regulated to "Kinder," "Küche," and "Kirche" (children, kitchen, and church). ${ }^{9}$ By focusing primarily on the family and the home, the Nazis believed a woman could simultaneously fulfill her own natural maternal instincts and serve the state to the best of her abilities. ${ }^{10}$ In Nazi society, mothers were also to be accorded with the same honourable status as the soldier in the German Volk community. For the Nazis, in becoming a mother, a woman sacrificed her body and life for the good of the Fatherland, much like the soldier. ${ }^{11}$ Motherhood was also compared to soldiering in that by brining a child into the world, a mother was thought to be fighting her own battle for the nation. ${ }^{12}$ Therefore, in embracing motherhood, women were afforded due prestige in Nazi Germany.

\section{Origins of Nazi Ideology on Gender}

Nazi attitudes towards gender and gender roles primarily stemmed from existing fascist ideology and nineteenth century philosophy in which the regime appropriated to serve their ideological ambitions. One such philosopher that was fundamental in influencing the Nazi view on gender and the overall fascist rhetoric on the establishment of a 'new man' was Friedrich Nietzsche. According to Nietzsche, willpower and healthy emotions should dominate over repression. In mastering his emotions, a man could then become Übermensch or the "overman," which is a type of superior human being that has achieved self-mastery and has balanced thoughts and feelings. ${ }^{13}$ The idea of the 'new man' was first introduced in Italy by extreme nationalists who wanted to establish a new Italy. ${ }^{14}$ The Futurists, who had a significant role in the institution of fascism in Italy, also embraced the notion of creating a 'new man'. To the Futurists, the new Italian man was not weighed down by history "but could take off into uncharted spaces proclaiming Italy's glory through his personal drive

\footnotetext{
${ }^{5}$ Lisa Pine, Nazi Family Policy, 1933-1945 (New York: Berg, 1997), 45.

${ }^{6}$ Cited by Irene Guenther, Nazi Chic?: Fashioning Women in the Third Reich (New York: Berg, 2004), 93.

${ }^{7}$ Guenther, Nazi Chic?, 95.

${ }^{8}$ Cited by Guenther, Nazi Chic?, 95.

${ }^{9}$ Guenther, Nazi Chic?, 95.

${ }^{10}$ Ibid., 95.

${ }^{11}$ Ibid., 93.

${ }^{12}$ Ibid., 95.

${ }^{13}$ Stanley G. Payne, A History of Fascism, 1914-1945 (Madison, WI: The University of Wisconsin Press, 1995), 24-25.

${ }^{14}$ Mosse, The Image of Man, 156.
} 
and energy." 15 Furthermore, the Futurists believed that the 'new man' was to be disciplined, combative, and perceive the world in a way that accepted the new speed of time. ${ }^{16}$ Therefore, in taking power, Mussolini adapted many of the existing theories on the 'new man' into fascist ideology. In creating a fascist new man, Mussolini was also influenced by the work of Italian publicist Giovanni Papini who stated that men were to rid themselves of bourgeois icons such as family and love. Papini also emphasised that men must be forceful and energetic and approach life in a sober, unromantic manner. ${ }^{17}$ Thus, when Mussolini came to power in Italy, establishing a fascist 'new man' was fundamental to his political agenda. Consequently, the concept of the 'new man' became a significant aspect of fascist ideology as a whole.

The glorification of the war also had a considerable impact on Nazi gender ideals. After the Great War, there was an extensive effort to redefine masculinity in Germany and other various countries. Ultimately, the Nazis saw themselves as the "inheritor[s] of the war experience." 18 As a result, war became a significant factor in determining masculinity in the Third Reich. According to the Nazis, the soldier represented true manhood because he was not afraid to face death and was willing to sacrifice himself for the good of the nation. It was also thought that a man who survived the war knew how to truly live because he defied death, resulting in the idolization of veterans in Nazi Germany. ${ }^{19}$ The wartime camaraderie felt between men also appealed to the Nazis. To the regime, male bonding was considered to be the foundation of the state. As a result, the idea of the Männerbund (male collective) was heavily promoted in Nazi Germany. ${ }^{20}$ Many of the Nazi's concepts on war and masculinity were also garnered from the writings of Ernest Jünger. For Jünger, war represented the end of the bourgeois era.21 Correspondingly, much of Jüngers writings glorified that act of war and emphasised its masculine qualities. In In Stablgewittern (Storm of Steel), Jünger describes man as being "a compulsive sexual being who proves himself in war.",2 Jünger also states that "for war, viewed from its centre...there is only one standpoint. It is the most masculine one." ${ }^{23}$ Therefore, combined with the glorification of the war experience, Jünger's writing had a significant influence on Nazi ideals regarding manhood and masculinity.

Nazi attitudes toward gender and gender roles were also affected by the Weimar Republic. For the Nazis, the Weimar Republic represented the cultural decay of German society. In order to prevent further cultural decomposition, the regime rejected all things associated with the Weimar period, including the new freedoms experienced by women. During the Great War, women were allowed leave the confines of the private sphere and seek employment in war-related industries. ${ }^{24}$ Following the war, women achieved a number of political gains including the establishment of female suffrage during the national election in November 1918, which led to the popularization of the women's emancipation movement. ${ }^{25}$ The new political empowerment of women at the beginning of the Weimar years led to dynamic changes in their conduct and behaviour throughout the 1920s. During

${ }_{16}^{15}$ Cited by Mosse, The Image of Man, 156.

${ }^{16}$ Mosse, The Image of Man, 156.

${ }^{17}$ Ibid., 157.

${ }^{18}$ Ibid., 158.

${ }^{19}$ Ibid., 158.

${ }^{20}$ Ibid., 158.

${ }^{21}$ Bernd Weisbrod and Pamela E. Selwyn, "Military Violence and Male Fundamentalism: Ernst Jünger's Contribution to the Conservative Revolution," History Workshop Journal 49 (Spring 2000): 80.

${ }^{22}$ Ibid., 79.

${ }^{23}$ Cited by Bern Weisbrod and Pamela E. Selwyn, "Military Violence and Male Fundamentalism," 79.

${ }^{24}$ Matthew Stibbe, Women in the Third Reich (New York: Oxford University Press, 2003), 11-12.

${ }^{25}$ Ibid., 12. 
the Weimar period, women were allowed to smoke, drink, and dance provocatively in public. ${ }^{26}$ Women also started to use cosmetics more regularly, cut their hair into styles such as the pageboy and the bob, and adopted male clothing into their wardrobes. ${ }^{27}$ Since the Nazis believed that racial purity would solve all of Germany's problems, they saw the 'masculinisation' of women as a significant threat. Consequently, the Nazis promoted the idea that feminism would destroy the German race and lead to the introduction of Bolshevism. ${ }^{28}$ The Nazis also denounced the women's emancipation movement as being a construct of the Jewish intellect. ${ }^{29}$ Furthermore, with the onset of the depression, the Nazis endorsed the notion that in order for the nation to recover economically, the family must be stabilized, which meant that women must return to the private sphere. ${ }^{30}$ Therefore, Nazi ideals on the role of women in society were developed in reaction to the freedoms experienced by women during the Weimar period.

\section{Ideology and Sexuality}

Sexuality was also a significant aspect of Nazi racial ideology. During the Weimar era, there was a considerable drop in birthrates, from 36 births per thousand inhabitants to 14.7 births per thousand. $^{31}$ The Nazis attributed this decline to the extravagant lifestyles of Germans during the Weimar period, which encouraged the promotion of the individual over the collective. ${ }^{32}$ For the Nazis, the low birthrate among the German population endangered the continued survival of the German/Aryan race. In order to promote a higher birthrate, the Nazis worked to control people's sexual behaviours. Under Nazi rule, the politicization of the body was incorporated in German societal discourses. ${ }^{33}$ According the Nazis, an individual's body is a public site "whose purpose was to further the larger social organism." ${ }^{34}$ As a result, private human activities were given public significance. ${ }^{35}$ To ensure the perseverance of the German/Aryan race, the Nazis embraced conservative sexual values, which emphasised heterosexuality and chastity. When it came to the actual act of sex, the Nazis believed that people should approach sex with the purpose of fulfilling national goals rather than pursuing their own pleasure. ${ }^{36}$ Ultimately, immoral sexual practices, such as homosexuality, were blamed on the Jews. To the Nazis, the Jews sought "to strike the Nordic race at its most vulnerable point: sexual life." ${ }^{37}$ The Nazis also argued that the Jews disregarded spirituality in exchange for sensuality and physical contact. ${ }^{38}$ Thus, the Nazis advocated the idea that proper sexual behaviours were devoid of Jewish influences.

${ }^{26}$ Guenther, Nazi Chic?, 54.

27 Ibid., 54.

${ }^{28}$ Stibbe, Women in the Third Reich, 17.

${ }^{29}$ Guenther, Nari Chic?, 95.

${ }^{30}$ Stibbe, Women in the Third Reich, 23.

31 Pine, Nazi Family Policy, 9.

${ }^{32}$ Ibid., 9.

${ }^{33}$ Gordon, "Fascism and the Female Form," 164.

${ }^{34}$ Ibid., 164.

35 Annette F. Timm, "Sex with a Purpose: Prostitution, Venereal Disease, and Militarized Masculinity in the Third Reich," Journal of History of Sexuality 11, no. 1/2 (January 2002): 223.

${ }^{36}$ Ibid., 225.

${ }^{37}$ Cited by Dagmar Herzog, "Hubris and Hypocrisy, Incitement and Disavowal: Sexuality and German Fascism," in Sexuality and German Fascism, ed. Dagmar Herzog (New York: Berghahn Books, 2005), 4.

${ }^{38}$ Herzog, "Hubris and Hypocrisy," 4. 


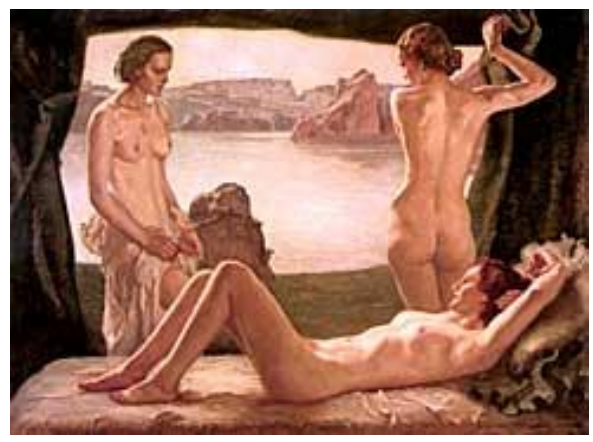

Sexuality for the Nazis also represented an area in which the regime could further consolidate its power. ${ }^{39}$ For the Nazis, regulating public discourse on acceptable sexual practices allowed the regime to be associated with sexual gratification. By enforcing the idea that sex was a public service, the individual would then recognize their sexual satisfaction as being a part of their patriotic duty in supporting the Nazis and their endeavours. ${ }^{40}$ As a result, sex was considered to be a reward for the regime to dole out to its supporters. ${ }^{41}$ The Nazis also worked to eliminate the existing taboos associated with sexuality. They claimed that sexual taboos associated with the body were introduced into German society by the Jews in an effort to disturb the natural order and undermine institutions such as marriage and the family. ${ }^{42}$ The goal of the Nazis was to restore notions of beauty and nobility back to the body. ${ }^{43}$ In order to accomplish this task, the regime instituted specific standards about how the body, particularly the female body, should be portrayed in paintings and other artistic creations. To the Nazis, artists were to strive to represent the purity of the body in its natural form in their work. Thus, many Nazi-commissioned paintings feature psychically attractive women lying naked in the sun or in the sea, such as in Ernst Liebermann's painting "By the Sea." ${ }^{44}$ All forms of artwork that did not fulfill the standards set in place by the Nazis were classified as 'degenerate art' because of its supposed advocacy of sexual deviance, pornography, and nakedness. ${ }^{45}$ Therefore, by imposing their own ideals on sexuality onto society, the Nazis presented themselves as the protectors of sexual morality and good taste while also "pander[ing] to the pleasures of looking." ${ }^{46}$

Although the Nazi stance on sexuality appeared to be regressive and rigid, there were a number of contradictions between what the Nazis outwardly promoted and what was actually practiced. In order to achieve their racial ambitions, the regime encouraged premarital sex and extra-marital affairs. While the Nazis heavily advocated the idea of chastity, by 1934, members of the Bund Deutscher Mädel (Federation of German Girls) were instructed to engage in premarital relations. ${ }^{47}$ Although this directive was originally classified as "top secret," by 1935 the population was well aware of what went on during meetings between the BDM and the Hitlerjugend $(\mathrm{HJ})$ or Hitler Youth. ${ }^{48}$ As a result of these illicit affairs, hospitals became overcrowded with adolescent girls, some as young as fifteen, who were either pregnant or had sexually transmitted infections. ${ }^{49}$ Due to the influx of un-wed mothers during the mid to late 1930s, the Nazis also worked to eliminate the stigma associated with single mothers and illegitimate children. According to Nazi Family Policy, "the National Socialist state no longer sees in the single mother the 'degenerate'...It places the single mother who has given a child a life higher than the 'lady,' who has avoided having children in her

\footnotetext{
${ }^{39}$ Ibid., 3.

${ }^{40}$ Ibid., 9.

41 Timm, "Sex with a Purpose", 226.

${ }^{42}$ Herzog, "Hubris and Hypocrisy," 12.

${ }^{43}$ Ibid., 12.

${ }^{44}$ Ibid., 12

${ }^{45}$ Ibid., 12.

${ }^{46}$ Ibid., 12.

${ }^{47}$ Ibid., 8.

${ }^{48}$ Ibid., 8-9.

${ }^{49}$ Ibid., 8.
} 
marriage on egotistical grounds." ${ }^{50}$ Moreover, during the war years, SS leader Heinrich Himmler even went as far as to endorse polygamy. For Himmler, traditional marriages would not produce the amount of children needed to cement the future of the German/Aryan race. Himmler believed that with having multiple wives, a man would be less tempted to stray because each wife would vie for his affections. ${ }^{51}$ Therefore, it is evident that there was a specific duality between what the Nazis preached and what they practiced in terms of sexuality.

This duality also existed when it came to Nazi attitudes regarding prostitution. During the Nazi period, there was a wide-spread campaign to eliminate venereal disease (VD), which was deemed hazardous to the foundation of the state. In May 1933, revisions were made to the VD law, which was included in the Decree for the Protection of the Volk and State, and Clause 361 of the criminal code that allowed the Nazis to punish those "who publicly and conspicuously or in a manner likely to annoy the public incites immoral acts or offers immoral services." 52 Those who were considered promiscuous or engaged in sexually deviant activities, such as prostitutes, were categorized as 'asocial' or people unwilling to integrate themselves into society. ${ }^{53}$ The Nazi ideology outwardly idealized chastity and moral sexual practices, but did not ban prostitution entirely. While the Nazis imposed heavy penalties on prostitutes who did not comply with health regulations, the regime was much more lax in enforcing laws against the establishment of brothels and red light districts. ${ }^{54}$ Although health care experts argued that brothels and red light districts raised the risk of spreading VD among the population, the Nazis condemned these reports. Instead, the regime insisted that brothels and controlled prostitution protected public health because it ensured that young men would not resort to homosexuality to fulfill their sexual desires. ${ }^{55}$ The Nazis also thought that soldiers were strengthened through their encounters with prostitutes because it enabled them to fight with more vigor. ${ }^{56}$ Consequently, in 1936 the Supreme Command of the Webrmacht declared military brothels to be a necessity and a state run brothel system was introduced. ${ }^{57}$

\section{Enforcement}

In order to indoctrinate their ideals on gender and sexuality into society, the Nazis used a number of different methods. One such method was the institution of laws and policies aimed towards achieving Nazi racial ambitions. Between the period of September to October 1935, the regime introduced several laws that effectively eliminated the freedoms associated with marriage in Germany. ${ }^{58}$ Under the "Marriage Health Law," couples who wished to be wed were forced to provide evidence that proved their hereditary fitness in order to demonstrate that their marriage would produce racially pure children. ${ }^{59}$ Furthermore, during the war, military marriage regulations were instituted and brides were subjected to additional physical examinations. ${ }^{60}$ However, men who

\footnotetext{
${ }^{50}$ Cited by Pine, Nazi Family Policy, 39.

${ }^{51}$ Pine, Nazi Family Policy, 39.

52 Cited by Timm, "Sex with a Purpose," 234.

53 Timm, "Sex with a Purpose," 234, 243.

${ }^{54}$ Ibid., 237-238.

55 Ibid., 238.

${ }^{56}$ Ibid., 227.

57 Ibid., 238.

58 Gabriele Czarnowski, "The Value of Marriage for the Volksgemeinschaft: Policies Towards Women and Marriage Under National Socialism," in Fascist Italy and Nazi Germany: Comparisons and Contrasts, ed. Richard Bessel (New York: Cambridge University Press, 1996), 101.

59 Ibid.,101-102.

${ }^{60}$ Ibid., 102.
} 


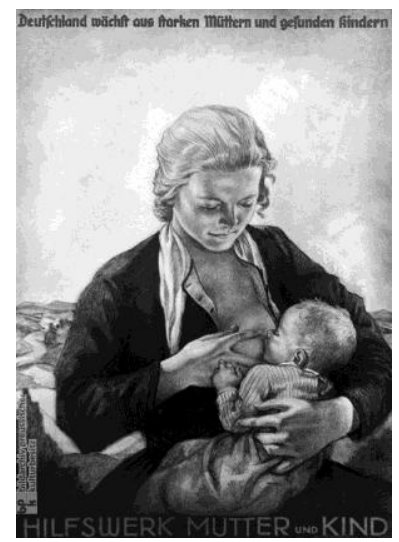

were qualified to serve in the military were declared fit for marriage and were not required to submit to further testing. In 1941, the Nazis also introduced the "Marriage Clearance Certificate," which was specifically aimed towards women. Since men in the military were considered 'hereditarily fit,' this directive was enacted to prevent marriage fraud by women whose offspring would be regarded as undesirable. ${ }^{61}$ Laws and policies were also set in place in an effort to drive women from the workplace. Under the Nazi rule, the policy against Doppelverdiener or 'double earners,' which was first established during the Weimar period, continued to be enforced. ${ }^{62}$ According to the Nazis, married women who were employed in heavy industry limited available job opportunities for men and as a result, those unemployed men would not be able to provide for their own families. Although women were not entirely banned from working in the industrial sector, they were encouraged to work in areas more suited to their 'biology' or to participate in tasks that would not distract them from their family duties, such as working in assembly lines. ${ }^{63}$

The Nazis also heavily employed propaganda in the form of images, films, and other media-based sources in an effort to instill their ideals in the German population. Like other authoritarian or

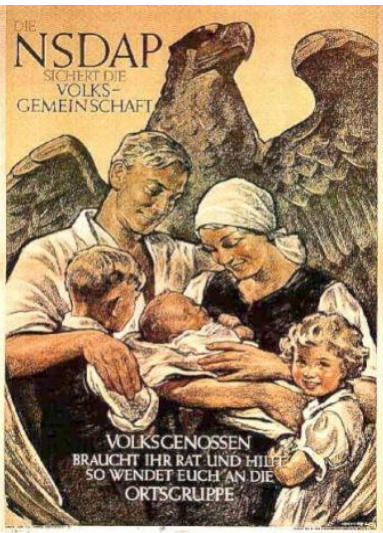
totalitarian regimes, the Nazis understood the potential of propaganda to have a significant influence on the private lives of citizens. ${ }^{64}$ In their propaganda campaign, the Nazis idealized their ideology regarding gender and sexuality. In order to induce women to embrace motherhood and domestic life, propaganda materials, such as posters, often depicted women as mothers, basking in the joys of raising a family. Women were frequently pictured breast-feeding a baby or surrounded by children in a traditional rural setting, which was meant to represent the Nazi

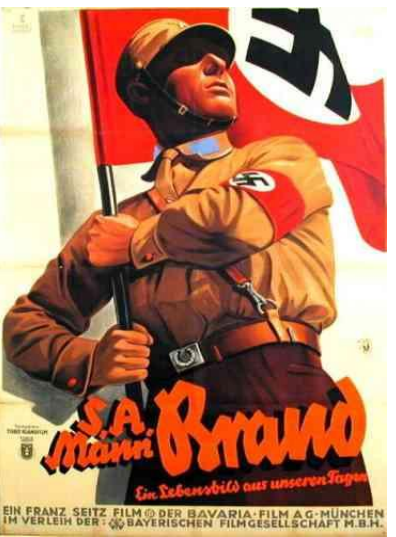
fantasy of ideal family life. ${ }^{65}$ Men, on the other hand, were primarily depicted as soldiers prepared to go to war for the Fatherland, which emphasized the values of heroism and self sacrifice that the Nazis associated with masculinity. To symbolize the importance of family and racial purity, men with obvious Aryan characteristics were also included in pictures of the kinderreich family looking happy and healthy. ${ }^{66}$ The Nazis also published various kinds of propaganda literature in order to further indoctrinate the population. Specialized women's magazines that informed the reader about the joys of motherhood, gave marriage advice, and offered tips on how to manage the household were widely circulated. ${ }^{67}$ These magazines also included articles geared towards men, such as "The Happy SS Father."68 The Nazis also distributed pamphlets, created traveling art exhibits, and made

\footnotetext{
61 Ibid., 102.

62 Pine, Nazi Family Policy, 20.

${ }^{63}$ Ibid., 20-21.

${ }^{64}$ Stibbe, Women in the Third Reich, 40.

${ }^{65}$ Ibid., 40-41.

${ }^{66}$ Pane, Nazi Family Policy, 98.

${ }^{67}$ Guenther, Nazi Chic?, 96.

${ }^{68}$ Ibid., 96.
} 
radio broadcasts and public speeches to further promote their ideology on gender and sexuality. ${ }^{69}$ Therefore, one can see that the Nazis employed a number of different mediums as tools in their propaganda efforts.

The Nazis also worked to indoctrinate German citizens through the use of educational programs. According to Nazi leader Adolf Hitler, the goal of education was to teach girls and boys about becoming mothers and soldiers. ${ }^{70}$ As a result, the Nazis established the HJ and BDM as institutions in which young Germans could be instructed on Nazi ideology and molded into proper Nazi citizens. In both organizations, girls and boys were instructed on their obligations to the Volk and taught about health and racial purity. Moreover, in the HJ and BDM, physical activity was emphasized with boys and girls being trained to endure a certain amount of physical labor. Thus, members of the $\mathrm{HJ}$ and BDM were strictly disciplined into complying with organizational principles and Nazi standards. ${ }^{71}$ Educational programs were also directed towards adults, especially women. Through the establishment of the NS-Frauenschaft, a Nazi women's organization, a "Mother Schooling Program" was introduced. ${ }^{72}$ In enrolling in this program, women over the age eighteen were taught about their duties as a wife and mother, as well as instructed on how to properly care for their home and family. By the end of 1936, over 150 schools were instituted, which eventually rose to 270, with 673000 women attending. ${ }^{73}$ The Reichsfrauenführung (National Women's Leadership) also developed a new a branch within the Deutsche Frauenwerk (German Women's Work) that worked to educate women about the regime's autarky program. ${ }^{74}$ In lectures hosted by this new department, National Economics/Home Economics ( $\mathrm{Vw} / \mathrm{Hw}$ ), women were instructed on purchasing products that would contribute to the national good, such as refraining from buying goods from Jewish shops. ${ }^{75}$ Women were also told to purchase only locally grown produce, such as apples, instead of imported fruits, as well as encouraged to recycle old clothes and household products. ${ }^{76}$ Thus, it is evident that educational programs were an important source for imposing Nazi ideals onto the German population.

\section{Impact}

Nazi ideology regarding gender and sexuality had a number of effects on the German population. Although the Nazis considered the family the foundation of the nation, Nazi attitudes towards gender and sexuality worked to undermine the family unit. Ultimately, the emphasis placed on fulfilling a triumphant form of masculinity created tension between men and their families. ${ }^{77}$ More specifically, there was a distinct rivalry between all-male party organizations and family life. In joining such organizations as the S.A. or Sturmabteilung, men often faced the dilemma of living up to Nazi ideals associated with masculinity and also honoring their obligation to establish a family and father racially pure children. For members of the S.A., a man's loyalty belonged to the state and as a result, there was little concern for the family. ${ }^{78}$ It was also commonly understood that a man's purpose in life was to serve the state. Thus, a man could not be contained within the confines of the

\footnotetext{
69 Ibid., 97.

${ }^{70}$ Pine, Nazi Family Policy, 47.

${ }^{71}$ Ibid., 49.

72 Guenther, Nari Chic?, 97.

${ }^{73}$ Ibid., 97.

${ }^{74}$ Ibid., 97.

${ }^{75}$ Ibid., 97.

${ }^{76}$ Ibid., 97-98.

${ }^{77}$ Mosse, The Image of Man, 166.

${ }^{78}$ Ibid., 166.
} 
home. $^{79}$ This rivalry between the state and the family was represented in the film Kolberg (1945), in which a German officer forsakes the love of an idealistic woman because he prefers the masculine world of fighting for the Fatherland over settling down and starting a family. ${ }^{80}$

Youth organizations also worked to undermine the institution of the family in Nazi Germany. While the $\mathrm{HJ}$ and the BDM were established with the intention of supporting the family unit, many youths saw these groups as a means to gain a degree of independence outside of their families and contribute to the adult world. ${ }^{81}$ Children were subjected to strong parental discipline and scrutiny, with boys and girls often feeling intimidated by their fathers. As a result, some children joined these organizations as an act of rebellion against their parent's authority. ${ }^{82}$ The youth leagues in Nazi Germany also worked against the institution of the family in that members were used as informants. In joining the $\mathrm{HJ}$ and the BDM, inductees were made to swear an oath of allegiance to the Fübrer (leader). ${ }^{83}$ Also, in these organizations, members were expected to accept Nazi ideology and their obligations to the Volkesgemeinschaft (national community) unquestionably. ${ }^{84}$ When conflicts arose between family demands and Nazi ideals, children involved in the HJ and the BDM were instructed to take actions against their parents and notify officials. ${ }^{85}$ Although public denouncements of parents were prohibited, the family became "an organization for the terror of formal domination." 86 By indoctrinating the youth, the Nazis stripped parents of qualities that garnered respect from their children. $^{87}$

Nazi laws and policies regarding gender and sexuality also had a considerable impact on the German population. As an incentive to promote more marriages between 'hereditarily fit' partners, the Nazis established the Law for the Reduction of Unemployment in June 1933 which allowed couples to apply for interest-free loans of up to RM $1000 .{ }^{88}$ In order to acquire a marriage loan, however, the women would have to give up paid employment. Therefore, this law was instituted with the hopes that it would remove women from the public sphere and increase available job opportunities for men. The Nazis believed that the establishment of marriage loans would reduce the male marriage age and decrease a man's need to engage in illicit sexual activities, such as prostitution. ${ }^{89}$ Also, the Nazis introduced a number of changes to the existing divorce laws in Germany. One such change was dissolving marriages based on infertility or the refusal of a spouse to procreate. According to the Nazis, marriages that did not produce racially pure children were useless to the national community. If no children could be produced either by circumstance or by choice, a wife or husband had legitimate grounds to divorce their partner. ${ }^{90}$ While the new divorce laws were not meant to be biased towards a particular sex, men were more successful in incorporating National Socialist ideals into their complaints. As a result, men were frequently granted divorces against their reluctant

\footnotetext{
${ }^{79}$ Ibid., 167.

${ }^{80}$ Ibid., 166.

${ }^{81}$ Pine, Nazi Family Policy, 48.

${ }^{82}$ Ibid., 48.

${ }^{83}$ Klaus Theweleit, Male fantasies, vol. 2, trans. Erica Carter and Chris Turner in collaboration with Stephen Conway (Minneapolis: University of Minnesota Press, 1989), 252.

${ }^{84}$ Pine, Nazi Family Policy, 48.

85 Theweleit, Male fantasies, 252.

${ }^{86}$ Ibid., 252.

${ }^{87}$ Ibid., 252-253.

${ }^{88}$ Pine, Nazi Family Policy, 17.

${ }^{89}$ Ibid., 17.

${ }^{90}$ Czarnowski, " "The Value of Marriage for the Volksgemeinschaft, 105.
} 
spouses. ${ }^{91}$ Furthermore, Germans who failed to marry or remained childless faced various penalties. Un-wed or childless women were pitied and chastised in public and in private, as well as subjected to public stigmatization for working against the nation. Unmarried men and childless couples who 'refused to multiply' (Fortpflanqungsverweigerung), however, were required to pay additional taxes that amounted to ten percent of their income as punishment. ${ }^{92}$ Therefore, Nazi laws and policies concerning gender and sexuality further enforced Nazi ideals on acceptable gender roles, sexual practices, and racial purity.

Since gender and sexuality was a significant aspect of the Nazi population policy, it is also pertinent to discuss the different ways in which the German population was affected by Nazi attitudes concerning racial hygiene. According to the Nazis, controlling people's reproductive capacities would allow for the growth of a healthier and productive nation due to the purity of population. ${ }^{93}$ Consequently, the Nazis introduced the Law of for the Prevention of Hereditarily Diseased Offspring in July 1933. Under the jurisdiction of this law, those who were suffering from a 'hereditary disease', such as 'congenital feeble-mindedness', 'schizophrenia', and 'manic depression', were subject to compulsory sterilization. Between the period of January 1934, when the law was officially implemented, and September 1939, approximately 320000 Germans (0.5 percent of the population) were sterilized. ${ }^{94}$ Moreover, most of those who were sterilized were classified as 'feebleminded', although the Nazis did not have a set criteria for determining 'feeble-mindedness' at the time. ${ }^{95}$ While compulsory sterilization applied to both of the sexes, more than two-thirds of people who were sterilized were women. Victims of sterilization also consisted of ethnic Germans from the poorest sectors of society, minority groups, and inmates of psychiatric institutions and jails. ${ }^{96}$ In 1939, Nazi efforts to sterilize those considered to be 'undesirable' took a more sinister turn with the establishment of the euthanasia or "T 4" project; between 1939 and 1941, over 100000 people who were institutionalized and classified as "useless eaters" by the Nazi regime were either euthanized or killed by starvation. ${ }^{97}$ According to the historian Gisela Bock, the sterilization and euthanasia of German men, women, and children prior to the Second World War was the foundation on which the Nazis built their extreme attitudes regarding the liquidation of the European Jewry. ${ }^{98}$ Thus, one can see that Nazi ideology on racial purity also had a significant impact on the non-Jewish population of Germany.

Nazi ideals concerning gender and sexuality also had a considerable effect on women in the Third Reich. Although the Nazi state was strictly anti-feminist, they did provide welfare programs for mothers and their children. Mothers, especially those who were unmarried, could apply for state welfare, although the assistance that was given to them was not in the form of financial aid. Instead, the Nazis supplied mothers with materials such as beds, linens, and children's clothes. Furthermore, women who were pregnant were visited by health care officials, such as nurses, and examined regularly in order to ensure that they did not miscarry. ${ }^{99}$ Despite the support provided by the state

${ }^{91}$ Ibid., 106.

${ }^{92}$ Stibbe, Women in the Third Reich, 50.

${ }^{93}$ Pine, Nazi Family Policy, 11.

${ }^{94}$ Ibid., 13.

${ }^{95}$ Ibid., 13-14.

${ }^{96}$ Ibid., 13-14.

${ }^{97}$ Gisela Bock, "Racism and Sexism in Nazi Germany: Motherhood, Compulsory Sterilization, and the State," Signs 8, 3 (Spring 1983): 415.

${ }_{98}$ Ibid., 415.

${ }^{99}$ Pine, Nari Family Policy, 24. 
for mothers, a number of women still succumbed to the pressures of living up to the Nazi ideal. Under the Nazi regime, recuperation centers were established for mothers who wished to leave their families for an extended period of time. While women who attended these facilities were said to be on vacation, it is clear that many women were sent to recuperation centers because of their inability to fulfill all of their motherly duties. ${ }^{100}$ As a result, these centers had a strong educational foundation in which women were instructed about their obligations to their families and the Volk community. When these women returned to their families, it was thought they would have a renewed strength of spirit and a better understanding about their roles as wives and mothers. ${ }^{101}$ This notion that women found it difficult to comply with the standards of the Nazi regime is also emphasized in the writings of Gisela Bock. According to Bock, women who either did not want children or were somehow endangered by childbirth had motherhood forced down upon them. Motherhood in the Third Reich represented a kind of forced labor in that women were required to tolerate "the labor of childbirth in its modern misogynist form and the labor of additional unpaid housework." 102 Thus, due to the Nazi ideals on gender and sexuality, women in Nazi Germany endured significant amounts of hardships in working to fulfill their obligations to the nation.

Nazi ideology on gender and sexuality also resulted in considerable consequences for homosexual individuals. For the Nazis, people who engaged in homosexual activities were considered to be 'degenerate', 'unhealthy', or 'alien to the species'. ${ }^{103}$ As a result, homosexuals were excluded from the Volksgemeinschaft because they could not fulfill their obligation to the nation by reproducing. The Nazis also believed that homosexual men were the antithesis of the masculine ideal because they lacked the capacity and mental strength to not give into their physical urges and sexual perversions. Homosexual men were also thought to be soft, effeminate, and unable to express the heroic and self-sacrificing qualities valued by the Nazis. ${ }^{104}$ Therefore, the regime worked to abolish homosexual and gay culture from society by shutting down known gay bars and clubs and dissolving organizations that supported homosexual rights, such as Max Hirschfield's Institute for Sexology. ${ }^{105}$ In 1935, the Nazis also introduced a sub clause to the German penal code that gave the party the jurisdiction to punish or imprison those who were thought to be homosexual. ${ }^{106}$ People who were denounced as homosexuals, particularly men, often lost their jobs, homes, friends, and even their lives. While it was not the goal of the Nazis to eliminate homosexuals all together, men and women found guilty of homosexuality were often shipped to concentration camps, in which homosexual men were frequently castrated or killed. ${ }^{107}$ Thus, one can see that Nazi attitudes towards sexuality had tragic effects on homosexual individuals in that they were subjected to the same harsh treatment as other minorities, such as the Jews.

\section{Conclusion}

Ultimately, the Nazis pursuit of racial purity had a significant influence on their ideology regarding gender and sexuality. Under the Nazi regime, traditionalist notions on gender and sexuality were

\footnotetext{
${ }^{100}$ Ibid., 26-27.

101 Ibid., 27.

102 Bock, "Racism and Sexism in Nazi Germany," 412.

103 Stefan Micheler, "Homophobic Progaganda and the Denunciation of Same-Sex-Desiring Men under National Socilaism," Journal of the History of Sexuality 11, no. 1/2 (January 2002): 96.

${ }^{104}$ Micheler, "Homophobic Propaganda and the Denunciation of Same-Sex-Desiring Men," 96.

105 Stibbe, Women in the Third Reich, 51.

106 Günter Grau, Hidden Holocaust?: Gay and Lesbian Persecution in Germany 1933-1945, trans. Patrick Camiller (Chicago: Fitzroy Dearborn, 1995), 65.

${ }^{107}$ Micheler, "Homophobic Propaganda and the Denunciation of Same-Sex-Desiring Men," 129.
} 
introduced into German society, which stripped both men and women of their freedoms associated with the body. Primarily, the Nazis promoted the idea that masculinity was determined by a man's ability to express heroic and self-sacrificing qualities. On the other hand, a woman's femininity was defined by her embracing her maternal instincts and becoming a mother. Nazi attitudes towards sexuality were also conservative in nature, although there were numerous contradictions between Nazi sexual ideals and what the regime actually practiced. In order to enforce their gender and sexual values in the population, the Nazis engaged a number of methods, including the institution of various laws and policies and the employment of propaganda. As a result, Nazi ideology had considerable impact on German society, including the undermining of the institution of the family, the sterilization of both men and women, and the imprisonment of homosexuals. Therefore, by examining the importance of gender and sexuality in Nazi racial ideology, one can see that the nonJewish German population was also subjected to significant hardships during the Nazis time in power. 


\section{Bibliography}

Bock, Gisela. "Racism and Sexism in Nazi Germany: Motherhood, Compulsory Sterilization, and the State." Signs 8, 3 (Spring 1983): 400-421.

Czarnowski, Gabriele. “The Value of Marriage for the Volksgemeinschaft: Policies Towards Women and Marriage Under National Socialism.” In Fascist Italy and Nazi Germany: Comparisons and Contrasts, edited by Richard Bessel, 94-112. New York: Cambridge University Press, 1996.

Gordon, Terri J. "Fascism and the Female Form: Performance Art in the Third Reich." In Sexuality and German Fascism, edited by Dagmar Herzog, 164-200. New York: Berghahn Books, 2005.

Grau, Günter. Hidden Holocaust? Gay and Lesbian Persecution in Germany 1933-1945. Translated by Patrick Camiller. Chicago: Fitzroy Dearborn, 1995.

Guenther, Irene. Nari chic? Fashioning Women in the Third Reich. New York: Berg, 2004.

Herzog, Dagmar. "Hubris and Hypocrisy, Incitement and Disavowal: Sexuality and German Fascism." In Sexuality and German Fascism, edited by Dagmar Herzog, 1-21. New York: Berghahn Books, 2005.

Micheler, Stefan. "Homophobic Propaganda and the Denunciation of Same-Sex-Desiring Men under National Socialism." Journal of the History of Sexuality 11, no. 1/2 (January 2002): 95-130.

Mosse, George L. The Image of Man: The Creation of Modern Masculinity. New York: Oxford University Press, 1996.

Payne, Stanley G. A History of Fascism, 1914-1915. Madison, WI: The University of Wisconsin Press, 1995.

Pine, Lisa. Nazi Family Policy, 1933-1945. New York: Berg, 1997.

Stibbe, Matthew. Women in the Third Reich. New York: Oxford University Press, 2003.

Theweleit, Klaus. Male Fantasies. Vol. 2. Translated by Erica Carter and Chris Turner in collaboration with Stephen Conway. Minneapolis: University of Minnesota Press, 1989.

Timm, Annette F. "Sex with a Purpose: Prostitution, Venereal Disease, and Militarized Masculinity in the Third Reich." Journal of the History of Sexuality 11, no. $1 / 2$ (January 2002): 223-255.

Weisbrod, Bernd and Pamela E. Selwyn, "Military Violence and Male Fundamentalism: Ernst Jünger's Contribution to the Conservative Revolution," History Workshop Journal 49 (Spring 2000): 68-94. 